\title{
Efektifitas Pelatihan Keterampilan Tenaga Kerja \\ Dalam Meningkatkatkan Produktivitas
}

(Kajian Pada Mebel Batang Kelapa di Kelurahan Kota Uneng Kabupaten Sikka)

\author{
Yosef Moan Banda \\ e-mail: yosefmoan@gmail.com
}

Program Studi Pendidikan Ekonomi, FKIP Universitas Flores

\begin{abstract}
ABSTRAK: Fokus penelitian ini adalah kegiatan pelatihan keterampilan bagi tenaga kerja dan faktor-faktor penghambat yang mempengaruhi tingkat produktivitas mebel batang kelapa. Ada tiga masalah yang ingin ditelaah dalam penelitian ini adalah (1) Adakah kegiatan pelatiahn bagi tenaga kerja (2) Sejauh manakah pengaruh tenaga kerja terhadap produktivitas mebel batang kelapa (3) Adakah faktor-faktor penghambat dalam memproduksi mebel batang kelapa. Jenis penelitian ini adalah kualitatif dan kwantitatif secara terpadu. Dengan subyek penelitian sebanyak 10 responden terdiri dari 10 tenaga kerja dan manajer. Instrumen yang digunakan untuk pengumpulan data berupa observasi, wawancara, angket dan dokemuentasi, data terkumpul kemudian diolah dan dianalisis dengan menggunakan rumus koefisien korelasi product moment. Hasil penelitian menunjukan bahwa ada pengaruh yang signifikan dari pelatihan keterampilan tenaga kerja yang dimiliki terhadap peningkatan produktivitas mebel batang kelapa Maumere.
\end{abstract}

Kata kunci: efektivitas pelatihan tenaga kerja dan produktivitas.

ABSTRACT: The focus of this study is the skills training activities for the workforce and the inhibiting factors that affect the level of productivity of coconut stem furniture. There are three problems to be examined in this study are (1) Are there training activities for workere (2) The extent of the influence of labor on the productivity of coconut bar furniture (3) Are there any inhibiting factors in producing coconut stem furniture. This type of research is qualitative and quantitative integrated. With research subjects as many as 10 respondents consisting of 10 workers and managers. The instrument used for data collection in the form of observation, interviews, questionnaires and documentation, the data collected is then processed and analyzed using the product moment correlation coefficient formula. The results showed that there was a significant influence of the training of the skills of the workforce possessed in increasing the productivity of Maumere coconut stem furniture.

Keywords: effectiveness of workforce training, productivity. 


\section{PENDAHULUAN}

Tantangan yang dihadapi bangsa Indonesia saat ini adalah terjadinya proses globalisasi dan informasi, dimana era ini akan mengakibatkan praktek pasar bebas. Praktek pasar bebas berarti setiap transaksi terjadi tanpa mengenal batas-batas wilayah suatu negara sekalipun dari realisasi dan liberalisme ekonomni terjadi pada tahun 2020 nanti, namun gejalanya sudah terasa. Hal ini membuat pihak perusahaan dihadapkan pada tingkat persaingan yang sangat kompotitif. Untuk inilah, maka perusahaan harus mulai mempersiapkan diri dalam berbagai aspek agar mampu bersaing di pasar bebas. Salah satu upaya perusahaan adalah dengan mempekerjakan tenaga kerja yang terampil dan terlatih agar produktivitasnya dapat terjamin.

Aspek yang sangat urgen dalam mencapai tujuan perusahaan yakni Sumber Daya Manusia (SDM). Mengingat sumber daya manusia sangat menunjang organisasi dengan karya, bakat, kreativitas dan motivasi. Pengembangan indrustri dalam rangka pembangunan dilihat sebagai usaha untuk meningkatkan mutu sumber daya manusia antara lain dengan meningkatkan produktivitas usaha, dan kemampuan memanfaatkan secara optimal sumber daya alam dan daya produksi lainnya (Djojohadikusumo, 1985:8).

Faktor-faktor yang mempengaruhi produktivitas kerja karyawan adalah menyangkut kualitas dan kemampuan fisik pekerja yaitu pendidikan, pelatihan, etos kerja, sikap mental, (Simajuntak, 1998:38).

Faktor yang mempengaruhi produktivitas kerja karyawan yang dimaksud dalam penelitian ini adalah pelatihan dan keterampilan pada mebel batang kelapa Maumere. Perusahaan mebel batang kelapa. Mebel batang kelapa Maumere merupakan perusahaan yang dalam kegiatannya lebih banyak menggunakan tenaga kerja manusia dari pada mesin. Ada juga beberapa jenis mesin yang dimanfaatkan dalam mebel ini seperti mesin bor tangan, mesin roder tangan, mesin gergaji miring, mesin pengasah, mesin kompresor dan mesin pres. Dalam mendesain produk mebel sangat sederhana, produksi mebel batang kelapa sesuai dengan pesanan. Perusahaan terus mendorong peningkatan skill labour tenaga kerja dengan cara mengirim tenaga kerja ke Tomohon Menado Propinsi Sulewesi Utara guna mengikuti training (latihan).

Berdasarkan pengamatan penulis, bahwa rata-rata karyawan yang bekerja pada perusahaan mebel baang kelapa Maumere telah lama yaitu berkisar 5 sampai 10 tahun. Keterampilan yang dimilliki lebih bersifat bakat yang diperoleh dari orang tua dan berdasarkan pengelaman kerja pada tempat lain sebelum bekerja pada mebel batang kelapa di Kecamatan Alok Kabupaten Sikka.

Permasaahan yang ditemukan pada perusahaan mebel batang kelapa dewasa ini memproduksikan barang/jasa tidak memenuhi target karena kurangnya pelatihan - pelatihan yang mengakibatkan kecakapan dan keterampilan seorang tenaga kerja dalam proses pembuatan bahan-bahan produk mebel batang kelapa, sehingga berdampak pada hasil prodik barang-barang tidak meningkat. Disamping itu dijelaskan bahwa setiap tenaga kerja dalam menyelesaikan satu jenis produk berbeda antara satu dengan lainnya. Dari 10 Orang karyawan yang memproduksi satu jenis barang dalam hal ini meja, dengan jumlah produk yang ditargetkan oleh perusahaan mebel batang kelapa sebanyak 50 buah, yang dihasilkan dengan limit waktu 3 bulan hanya bisa diselesaikan oleh 4 orang tenaga kerja, sedangkan 6 orang lainnya jumlah produk yang dihasil tidak memenuhi target yang ditetapkan.

Pokok Permasalahan yang mau diteliti, dapat dirumuskan sebagai berikut: (1) Adakah kegiatan pelatihan keterampilan bagi tenaga kerja. (2) Sejauhmanakah pengaruh tenaga kerja terhadap produktivitas mebel batang kelapa? (3) Faktor-faktor penghambat yang 
mempengaruhi tingkat produktivitas mebel batang kelapa?

\section{LANDASAN TEORI Pelatihan}

Poerwadarminta,

(1996:563),

mengatakan pelatihan adalah proses, cara perbuatan melatih, kegiatan atau pekerjaan melatih. "Terlatih" adalah pandai atau berkemampuan, karena telah di latih, trampil karena sering berlatih. Latihan adalah pendidikan untuk memperoleh kemahiran atau kecakapan.

Pelatihan yang dimaksud dalam penelitian ini adalah pelatihan yang dilakukan secara rutin dalam kurun waktu tertentu agar daya kreasi terus dikembangkan yang bermuara pada prestasi kerja yang bersangkutan. Kemampuan seorang tenaga kerja dalam menyelesaikan suatu pekerjaan seringkali tergantung pada tingkat pengetahuan, keterampilan dan keahlian yang dimilki sesuai dengan pekerjaan yang dikerjakan. Keterampilan meruapkan salah satu faktor penentu untuk mengukur kecakapan dan kesanggupan seorang karyawan dalam melakukan pekerjaan, semakin lama keterampilan seorang pekerja diasah semakin baik pula produktivitas yang dihasilkan.

\section{Keterampilan Tenaga Kerja}

Abdulrahman (1992), mengatakan keterampilan tenaga kerja adalah pekerjaan atau kewajiban yang memerlukan suatu tingkat kecakapan dan keahlian yang tinggi, pada suatu tingkat yang dapat dipertimbangkan.

Selanjutnya Flipo (dalam Hendoyo; 1988:1) mengatakan bahwa keterampilan atau keahlian memerlukan suatu latihan yang agak lama yang pada dasarnya memerlukan pengetahuan dan kecakapan agar karyawan dapat mengenal suatu pekerjaan tertentu. Oleh sebab itu program latihan sebenarnya dapat mendekatkan kepentingan antara karyawan dengan pihak perusahaan. Pelatihan keterampilan tenaga kerja yang ada di perusahaan mebel batang kelapa seperti perakitan, pengolahan bahan dan persiapan pemasaran hasil produk.

Menurut Zainun, (1982) bahwa kemampuan seorang karyawan dalam menyelesaikan suatu pekerjaan seringkali tergantung pada tingkat pengetahuan, keterampilan dan keahlian yang dimilikinya. Keterampilan yang dimaksud adalah pekerjaan yang memerlukan suatu tingkat kecakapan dan keahlian yang tinggi,

\section{Produktivitas}

Produktivitas dapat diartikan sebagai ukuran tingkat efisiensi dan efektif dari setiap sumber daya yang digunakan selama produktivitas berlangsung. (Hartono, 1980:121). Menurut Ravianto, (1985:3), produktivitas adalah kemampuan seseorang atau sekelompok orang yang menghasilkan barang atau jasa yang ditujukan untuk menjadikan hari esok lebih baik dari hari ini. Produktivitas juga dapat dikatakan bahwa hasil dari seluruh sumber meskipun dinyatakan dalam perjam untuk setiap pekerja.

Sedangkan Saksono,(1988:184) mengatakan produktivitas adalah jumlah produk yang diberikan oleh setiap karyawan atau tenaga kerja dalam kurun waktu tertentu dan dinyatakan dalam unit. Nawawi, et al (1990:97) mengemukakan bahwa produkvitas kerja adalah perbandingan terbaik antara hasil yang diperoleh (output) dengan jumlah sumber kerja yang dipergunakan (input). Produktivitas kerja dikatakan tinggi jika hasilnya lebih besar, dari pada sumber kerja yang digunakan, sebaliknya produkvitas kerja dikatakan rendah manakala hasil yang diperoleh lebih kecil dari pada sumber kerja yang dipergunakan.

Dengan demikian berarti produktivita kerja sangat dipengaruhi oleh pemasaran yang dicapai atau tingkat pemanfaatan barang oleh masyarakat sebagai konsumen. Ada tiga gejala yang menggambarkan tingkat produktivitas adalah sebagai berikut:

1. Produktivitas Internal: yaitu tingkat pencapaian target mengenai barang 
yang dihasilkan oleh perusahaan sesuai rencana dalam waktu tertentu.

2. Produktivitas Eksternal: yaitu tingkat pemberdayagunaan atau pemanfaatan hasil yang dicapai suatu organisasi kerja oleh masyarakat. Dengan kata lain semakin tinggi pemanfaatan oleh masyarakat berarti semakin tinggi pula produktivitas organisasi kerja yang dihasilkannya.

3. Produktivitas Individu: yaitu Hasil kerja yang menggambarkan produktivitas bersumber dari kemampuan personil secara individu dalam bekerja. Produktivitas tersebut dapat dihitung dari perbandingan antara hasil kerja individu dalam bentuk uang dengan biaya yang dikeluarkan untuk individu tersebut sehingga dapat menghasilkan sesuatu. Disamping itu produktivitas individu tergambar dalam ketekunan, disiplin, ketepatan metode atau cara bekerja.

\section{Faktor-faktor yang Mempengaruhi Produktivitas Kerja}

Ada banyak faktor yang mmpengaruhi tingkat tinggi rendahnya produktivitas kerja karyawan. Faktor-fakto tersebut di kemukakan oleh Simanjuntak, (1998:38), sebagai berikut: (1) Pendidikan: Pendidikan masyarakat sangat terbatas, sehingga sangat membutuhkan kursus dan pelatihan yang nyata sehingga dapat memperluas wawasan tenaga kerja, sehingga mampu memproduktif. (2) Lingkungan Kerja: Lingkungan mempengaruhi karyawan melakukan pekerjaan, membutuhkan suasana yang mendukung kegiatan produktivitas. (3) Upah Minimum: Tingkat upah minimum juga mempengaruhi produktivitas, manakala upah tidak memenuhi kebutuhan fisik minimum, maka usaha-usaha peningkatan produktif turut mempengaruhinya. (4) Motivasi: Motivasi perlu diberikan kepada karyawan dalam rangka upaya peningkatan produktivitas. (5). Perjanjian Kerja: Perjanjian kerja bersama adalah alat yang menjamin akan hak dan kewajiban karyawan. Perjanjian kerja sama sebaiknya ada unsur-unsur penigkatan produktivias. (6.) Manajemen: Dalam rangka peningkatan produktivitas kerja, dianjurkan penerapan sistem manajemen pengendalian mutu terpadu. (7) Penerapan Teknologi: Fakta menunjukan bahwa kemajuan teknologi sangat mempengaruhi produktivitas, dalam hal ini pemerintah telah mengambil kebijakkan bahwa penerapan teknologi tepat guna berorientasi dalam mempertahankan program padat karya (labour intensive). (8) Adat Istiadat: Sering dijumpai bahwa adat istiadat juga menghambat peningkatan produktivitas, maka dianjurkan paling tidak mengurangi. (9) Kesempatan untuk Maju: Status karyawan harus berupa kepastian kerja, dan jejang karier perlu diklasifikasikan. (10). Sikap dan Etika Kerja: Sikap dan etika kerja harus dimiliki oleh seorang karyawan yaitu disiplin dan bertanggung jawab atas pekerjaannya.

\section{METODE PENELITIAN}

Jenis Penelitian yang digunakan dalam penelitian ini adalah kualitatif dan kuantitatif. Dengan pendekatan Deskriptif kualitatif, untuk memperoleh informasi dan keterangan-keterangan yang berhubuan dengan masalah yanh yang diteliti yakni sejauhmana karyawan memproduksi mebel batang kelapa dalam unit dan waktu tertentu dengan kepastian produk yang dihasilkan. Sedangkan pendekatan Desskriptif kuantitatif untuk menganalisis data dalam bentuk bilangan yang digunakan utuk mengukur produktifitas tenaga kerja.

Penelitian ini menggunakan dua variabel, yaitu variabel bebas dan variabel terikat. Yang yang dimaksud dengan varibel bebas adalah terkait pelatihan keterampilan tenaga kerja. Sementara variabel terika adalah produktivitas, antara kedua varibel ini mempunyai hubungan korelasi yang berkaitan dengan kegiatan pelatihan tenaga kerja dalam 
meningkatkan produktivitas mebel batang kelapa.

Pengumpulan data melalui data primer berupa obeservasi taknik obervasi ini untuk merekam data dengan cara mengamati keahlian dan keterampilan tenaga kerja. Sementara teknik wawancara, peneliti melakukan percakapan dengan dengan 9 orang karyawan dan manajer untuk memperoleh jawaban terhadap permasalahan yang sedang terjadi seperti proses produksi, jumlah karyawan dan jumlah produksi yang dihasilkan. Dan teknik angket, yaitu pengisian daftar pertanyaan berpedoman pada panduan yang sudah disiapkan untuk dijawab oleh responden. Sedangkan data sekunder diperoleh melalui dokumentasi. Yaitu mengumpulkan data-data non insani yang ada di mebel batang kelapa Maumere.

Analisis data dalam penelitian ini , digunakan dua cara, yaitu (1) analisis lapangan dan (2) analisis setelah data terkumpul. Untuk data kualitatif, terutama data tentang pelatihan keterampilan tenaga kerja dianalisis secara desakriptif.

Untuk mengetahui produktivitas tenaga kerja dengan dengan menggunakan teknik alaisis Korelasi Product Moment. Dengan Rumus sebagai berikut:

$$
r x y=\frac{N \cdot \sum X Y\left(\sum X\right)\left(\sum Y\right)}{\sqrt{\left\{N \cdot \sum X^{2}-\left(\sum X\right)^{2}\right\}\left\{N \cdot \sum Y^{2}-\left(\sum Y\right)^{2}\right\}}}
$$

\section{PEMBAHASAN}

Berdasarkan angket yang diedarkan kepada 10 orang yakni 9 orang karyawan dan manajer sebagai responden, selanjutnya hasil angket ini ditabulasi dan dibawakan ke distribusi hasil angket dan dianalisis dengan rumus Korlasi Product Moment sebagai berikut:

$$
\begin{array}{rllll}
\mathrm{N} & =10 & \sum \mathrm{X} 2 & =573 & \sum \mathrm{X}=75 \\
\Sigma \mathrm{Y} 2 & =442 & \sum \mathrm{Y} & =66 & \sum \mathrm{XY}=503
\end{array}
$$

Hasil perhitungan diperoleh rxy 0,98 kemudian di konsultasikan ke dalam rumus Spearman Brown. Hasil perhitungan diperoleh rxy $=0,989$ selanjutnya dikonsultasikan dengan tabel nilai $\mathrm{r}$ 'Product Moment" untuk sumbyek $(\mathrm{N})=10$ orang dalam taraf signifikan $5 \%$ $=0,632$. Dan untuk taraf signifikan $1 \%=$ 0,765 .

Dari hasil perhitungan ternyata, memperoleh taraf sgnifikan yang tinggi. Dengan demikian hipotesis yang diajukan "Ada pengaruh yang signifikan dari kegiatan pelatihan keterampilan tenaga kerja terhadap peningkatan produktivitas mebel batang kelapa di Kelurahan Kota Uneng Kabupaten Sikka diterima kebenaranya.

Pelatihan Keterampilan kerja kaeryawan juga dapat mempengaruhi pekerjaan pada produksi mebel. Pelatihan keterampilan kerja yang dimaksud dalam penelitian ini adalah lamanya seseorang bekerja dalam bulan, Dengan pelatihan keterampilan ini berdampak pada keberhasilan dari usaha yang dikelola.

Tabel 1

Tenaga Kerja dan Lama Pelatihan

\begin{tabular}{|c|c|c|}
\hline No & Kode Nama Karyawan & Lamanya pelatihan (Bulan) \\
\hline 1. & H S & 6 \\
\hline 2. & R M & 6 \\
\hline 3. & M K & 6 \\
\hline 4. & T T & 6 \\
\hline 5. & F N & 6 \\
\hline 6. & R S & 3 \\
\hline 7. & A N & 3 \\
\hline 8 & A & 3 \\
\hline 9 & O N & 3 \\
\hline 10 & A. MT & 3 \\
\hline
\end{tabular}


Efektivitas Pelatihan Keterampilan Tenaga Kerja.

Kegiatan pelatihan keterampilan bagi tenaga kerja biasa diadakan di Tomohon Manado Propinsi Sulewesi Utara. Obyek pelatihan adalah mebel dan bangunan mekanik. Pelatihan yang disediakan dengan limit waktu 3 (tiga) sampai 6 (enam) bulan. Tenaga kerja yang mengikuti pelatihan selama 6 (enam) bulan senyak 5 orang pada gelombang pertama. Sedangkan gelombang ke dua juga sebanyak 5 orang selama 3 (tiga) bulan. Limit waktu yang diberikan baik 3 bulan maupun 6 bulan tidak membedakan bahwa latihan yang diberikan adalah berbeda.

\section{Produksi}

Untuk menjamin kelancaran proses produksi dan agar barang yang dihasilkan berkualitas tinggi, serta sesuai dengan selera konsumen, maka semua faktor atau kelengkapan yang dibutuhkan dalam proses produksi harus cukup tersedia, mulai dari bahan mentah, tenaga kerja, peralatan dan lainya yang menunjang proses produksi.

Selanjutnya kegiatan pelaksanakaan proses produksi dalam menghasil mebel adalah sebagai berikut:

a. Bahan baku yang digunakan untuk memperoduksi mebel adlah batang kelapa dan bahan penolongnya seperti lem, tripleks, paku,sekap, baut, bengkel, kunci, pelitur, dumpul dan kertas pasir.

b. Peralatan produksi yang digunakan dalam proses pembuatan mebel dapat dilihat pada tabel berikut ini:

Tabel 2

Peralatan Produksi Mebel

\begin{tabular}{|l|l|c|l|l|c|}
\hline No & \multicolumn{1}{|c|}{ Nama Peralatan } & Jumlah & No & Nama Perlatan & Jumlah \\
\hline 1. & Mesin Skap & 1 buah & 17 & Siku & 3 buah \\
\hline 2. & Mesin skap siku & 1 buah & 18 & Gergaji Kayu & 4 buah \\
\hline 3. & Mesin bor tangan & 2 buah & 19 & Gergaji besi & 4 buah \\
\hline 4. & Mesin Roder tangan & 1 buah & 20 & Kikir kayu & 2 buah \\
\hline 5. & Mesin Gergaji piring & 1 buah & 21 & Botol Sport & 4 buah \\
\hline 6. & Mesin Frais & 1 buah & 22 & Parang & 2 buah \\
\hline 7. & Mesin Pengasah & 1 buah & 23 & Obeng Plat & 2 buah \\
\hline 8. & Mesin Kompreson & 1 buah & 24 & Obeng Bunga & 2 buah \\
\hline 9. & Mesin Gergaji Pita & 1 buah & 25 & Tang besar & 2 buah \\
\hline 10 & Mesin Lem & 1 buah & 26 & Tang sedang & 2 buah \\
\hline 11. & Mesin Pres & 1 buah & 27 & Hamar besar & 1 buah \\
\hline 12. & Mesin Las & 1 buah & 28 & Hamar sedang & 2 buah \\
\hline 13. & Mesin Scroll Saw & 1 buah & 29 & Hamar kesil & 2 buah \\
\hline 14. & Mesin Amplas Tangan & 1 buah & 30 & Skrup: Panjang,sedang & 2 lusin \\
\hline 15. & Pahat 2,4 cm & 4 buah & 31 & Sersan & 6 buah \\
\hline
\end{tabular}

Berdasarkan paparan data, yang diperoleh dari hasil wawancara dengan tenaga kerja menunjukkaan bahwa untuk meningkatkan produktivitas tenagan kerja dengan baik, sebab jenis barang yang dikelola sesuai dengan selera konsumen dan mengikuti desain baru. Lebih dari itu dikatankan bahwa pelatihan kerja harus lebin kontinu agar produktivitas mebel batang kelapa dapat meningkat.
Berkaitan dengan kegiatan produksi yang dilakukan oleh perusahaan mebel batang kelapa, maka berikut ini dapat dilihat perkembangan usaha untuk setiap triwulan yang dihasilkan oleh karyawan dari jenis produk meja, berdasarkan target dan realisasi untuk setiap triwulan. Untuk jelasnya dapat dilihat pada tabel berikut ini. 
Tabel 3

Target dan Realisasi Jumlah Produk Setiap Triwulan

\begin{tabular}{|c|c|c|c|c|}
\hline Triwulan & Jenis Produk & $\begin{array}{c}\text { Target yang } \\
\text { ditetapkan }\end{array}$ & Realisasi & Selisih \\
\hline I & Meja & 40 buah & 39 buah & -1 \\
\hline II & Meja & 50 buah & 45 buah & -5 \\
\hline III & Meja & 50 buah & 50 buah & 0 \\
\hline IV & Meja & 50 buah & 55 buah & 5 \\
\hline
\end{tabular}

Berdasarkan tabel 3 diatass, dapat dilihat perkembangan kegiatan produksi dari setiap triwulan, yaitu utnuk triwulan pertama (1) jumlah produk dari jenis produk yang dihasilkan dan dibandingkan dengan triwulan kedua (2). Sedangkan untuk triwulan ke tiga (3) dan ke empat (4), jenis produk yang dihasilkan tersebut rata-rata telah mencapai target yang ditetapkan.

Berdasaarkan data yang diperoleh, dimana setiap tenaga kerja dalam menyelesaikan satu jenis produk meja berbeda antara satu dengan yang lainnya. Untuk lebih jelasnya dapat dilihat pada Tabel 4 berikut ini:

Tabel 4

Target dan Realisasi Jumlah Produksi dari setiap Karyawan

\begin{tabular}{|c|c|c|c|c|c|c|}
\hline Karywan & $\begin{array}{c}\text { Jenis } \\
\text { Produk }\end{array}$ & $\begin{array}{c}\text { Target } \\
\text { yang } \\
\text { diteapkan }\end{array}$ & $\begin{array}{c}\text { Produk } \\
\text { yang } \\
\text { dihasilkan }\end{array}$ & & Selisih & $\%$ \\
\hline & & & Jumlah & $\%$ & & \\
\hline 1 & Meja & 5 & 6 & 12,24 & 1 & 120 \\
\hline 2 & Meja & 5 & 7 & 14,24 & 2 & 140 \\
\hline 3 & Meja & 5 & 4 & 8,16 & -1 & 80 \\
\hline 4 & Meja & 5 & 6 & 12,24 & 1 & 120 \\
\hline 5 & Meja & 5 & 4 & 8,16 & -1 & 80 \\
\hline 6 & Meja & 5 & 4 & 8,16 & -1 & 80 \\
\hline 7 & Meja & 5 & 4 & 8,16 & -1 & 80 \\
\hline 8 & Meja & 5 & 3 & 6,12 & -2 & 60 \\
\hline 9 & Meja & 5 & 7 & 14,24 & 2 & 140 \\
\hline 10 & Meja & 5 & 4 & 8,16 & -1 & 80 \\
\hline
\end{tabular}

Berdasarkan tabel 4 diatas, nampak ada perbedaan dimana dari 10 karyawan yang memproduksi jenis meja, terjadi perbedaan dalam produk yang dihasilkan, yang ditargetkan dalam kurun waktu 3 bulan. Hal ini terlihat sesuai tabel, dimana nampak bahwa 4 karyawan $(1,2,4$ dan 9), jumlah produk yang dihasilkan melebihi target yang ditetapkan. Berarti 4 karyawan ersebut memiliki keahlian, keterampilan dan kreatif, juga mempunyai keuntungan dalam hal memproduksi meja. Sedangkan 6 karyawan yang lain $(3,5,6,7,8$ dan 10) jumlah produk yang dihasilkan tidak memenuhi target. Hal ini disebabkan oleh kurang pelatihan dan kreatif dakam memanfaatkan waktu, yang menyebabkan meja yang di produksi semakin hari semakin menurun. 


\section{KESIMPULAN DAN SARAN \\ Kesimpulan}

1. Produktivitas kerja dapat ditingkatkan manakala diadakan pelatihan keterampilan bagi tenaga kerja secara efektif dan efisien dalam mencapai sasaran dan tujuan yang telah ditetapkan.

2. Untuk memperoleh hasil yang baik, maka dalam menjalankan aktivitas perusahaan mebel batang kelapa diperlukan pembinaan bagi komponen atau karyawa-karyawan, terutama dalam peningkatan pelatihan dan keterampilan.

3. Dari hasil analisis data menunjukkan bahwa pelatihan keterampilan berpengaruh atas produktivitas kerja. Hal ini sebagai upaya nyata oleh perusahaan mebel batang kelapa di Kulurahan Kota Uneng Kecamatan Alok Kabupaten Sikka/

4. Keberhasilan pelatihan keterampilan bagi tenaga kerja akan berpengaruh atas produktivitas kerja dan memberikan kontribusi bagi perusahaan mebel batang kelapa dan

\section{Daftar Pustaka}

Abdul Rahman (1982) Ensiklopedi Ekonomi Keuangan Perdagangan. Jakarta: PT Predaya Paramita.

Edwin B. Tipo (1988) Berbagai macam bentuk pembinaan Tenaga Kerja

Hadari Nawawi A. Dan Kartini Hadan, (1990) Administrasi Personal Untuk Peningkatan Produktifitas Kerja, Jakarta: CV Haji Mas Agung.

Komarudin, (1981) Manajemen Organisasi Suatu Analisis Sistem, Bandung: Pn. Tarsito kebahagiaan dan kesejahtraan bagi tenaga kerja.

\section{Saran}

1. Perusahaan mebel batang kelapa Maumere dianjurkan untuk lebih meningkatkan keterampilan dengan cara mengikut sertakan tenaga kerja dalam kursus-kursus dan latihanlatihan yang berkitan dengan permebelan baik yang diberikan oleh pemerintah maupun perusahaan swasta atau lembaga sosial masyarakat.

2. Perusahaan mebel batang kelapa Maumere diharapkam memberi perhatian atas kesejahteraan keluarga dari tenaga kerj yang ada, agar tidak menimbulkan masalah dimana para pekerja meninggalkan tempat kerja tanpa alasan.

3. Dinas perindrustrian dan Perdagangan Kabupaten Sikka, diajurkan untuk memberikan dukungan kepada perusahaan mebel batang kelapa dalam hal manapun.

Peter F. Drucker, (1981) Manajemen Tugas Tanggung Jawab Praktek. Jakarta: PT Gramedia.

Rivianto J, (1980) Dasar-dasar Produktivitas

(1985), Produktivitas dan manusia Indonesia. Seri Produktivitas Cetakan I. Jakarta Pn Lembaga Sarana Informasi Usaha dan Produktivitas.

Saksono, (1980) Produktivitas Tenaga kerja, Jakarta

Sukanto Reksohadiprodjo dan Hani Handoko, (1980) Perdagangan dan Indrustri. Yogyakarta: Pn BPFE

Sumitro Djojohadikusumo, (1991) Perdagangan dan Instrustri dalam 
Pembangunan. Jakarta Pn.

Lembaga Penelitian Pendidikan dan Penerangan ekonomi dan Sosial

Tjiptaharyanto Prijono, (1989) Untaian Pengembangan Sumber Daya Manusia. Yogyakarta: BPFE

Slagi P. Sondang, (1993) Manajemen

Sumber Daya manusia. Jakarta Bumi Aksara 